\title{
MENINGKATKAN MOTIVASI BELAJAR SISWA MELALUI PELAKSANAAN TEAM TEACHING
}

\author{
Rahmawati \\ SMK Negeri 1 Robatal Sampang \\ Email: rahmawatiyus@gmail.com
}

\begin{abstract}
Abstrak:
Penelitian ini merupakan Penelitian Tindakan Kelas (PTK). Subjek dari penelitian ini adalah siswa kelas X yang berjumlah 32 siswa. Penelitian dilakukan dalam dua siklus dan setiap siklus terdiri dari dua kali pertemuan. Teknik pengumpulan data dalam penelitian ini menggunakan observasi dan angket. Data yang diperoleh dianalisis dengan cara reduksi, paparan data dan penyimpulan. Juga dilakukan analisis data deskriptif untuk data hasil observasi. Berdasarkan hasil penelitian, diperoleh kesimpulan bahwa pelaksanaan team teaching agar dapat meningkatkan motivasi belajar matematika yaitu guru kelas X sebagai guru 1 dan peneliti sebagai guru 2 melaksanakan tahap perencanaan yang meliputi: (1) Menyususun RPP dengan menetapkan metode pembelajaran kooperatif tipe belajar bersama (learning together). (2) Pembagian peran dan tanggung jawab guru anggota team teaching serta pembagian pos-pos pengawasan di dalam kelas. (3) Menyusun teaching material yang berisi materi, LKS, latihan soal dan penugasan terstruktur. (4) Menyiapkan media dan perangkat pembelajaran. Dari hasil observasi keterlaksanaan team teaching, pada siklus I mencapai $90,48 \%$ dan $100 \%$ pada siklus II. Hasil penelitian menunjukkan bahwa adanya peningkatan motivasi belajar siswa yang ditunjukkan dengan besarnya rata-rata persentase dalam angket motivasi belajar siswa, yakni secara keseluruhan pada siklus I sebesar $74,41 \%$ dengan kategori sedang menjadi $87,28 \%$ dengan kategori tinggi pada siklus II.
\end{abstract}

Kata Kunci: Motivasi Belajar, Team Teaching

\begin{abstract}
:
This research is a Classroom Action Research (PTK). The subjects of this study are students of class $\mathrm{X}$ which amounted to 32 students. The study was conducted in two cycles and each cycle consisted of two meetings. Data collection techniques in this study using observations and questionnaires. The data obtained were analyzed by means of reduction, data exposure and inferences. Also done descriptive data analysis for observation data. Based on the result of research, it can be concluded that the implementation of team teaching in order to increase the motivation to learn mathematics is the teacher of class $X$ as teacher 1 and the researcher as the teacher 2 carry out the planning phase which include: (1) RPP formulating by establishing cooperative learning method of learning together). (2) Division of roles and responsibilities of teachers of team teaching members and distribution of monitoring posts in the classroom. (3) Prepare teaching material containing material, LKS, practice questions and structured assignment. (4) Preparing media and learning tools. From the observation of the implementation
\end{abstract}


of team teaching, in the first cycle reached $90.48 \%$ and $100 \%$ in cycle II. The results showed that the increase in student learning motivation is indicated by the average percentage in the questionnaire of student learning motivation, that is overall in the first cycle of $74.41 \%$ with the category being $87.28 \%$ with the high category in cycle II.

Keywords: Learning Motivation, Team Teaching.

\section{Pendahuluan}

Matematika merupakan ilmu yang mempunyai peranan penting dalam perkembangan ilmu pengetahuan dan teknologi. Matematika menjadi alat bantu ilmu-ilmu lainnya, baik untuk kepentingan teoritis maupun aplikasi. Matematika merupakan subyek yang sangat penting dalam sistem pendidikan di seluruh negara di dunia ini. Negara yang mengabaikan pendidikan matematika sebagai prioritas utama akan tertinggal di segala bidang.

Perlakuan terhadap siswa secara individual lebih memungkinkan untuk berhasil mencapai tujuan pembelajaran daripada secara klasikal. Dalam hal ini pembelajaran yang melibatkan lebih dari seorang guru lebih bagus daripada hanya seorang guru saja. Menurut David W Beggs pembelajaran yang melibatkan lebih dari satu orang guru dalam waktu yang sama disebut dengan team teaching, suatu kegiatan yang melibatkan beberapa orang guru (kolaborasi) yang bertujuan untuk peningkatan mutu juga dalam menangani suatu persoalan yang dihadapi siswa pada saat kegiatan pembelajaran di kelas. ${ }^{1}$

Team teaching akan menjadi sangat menarik untuk dieksplorasi dan diterapkan lebih dalam jika dipahami secara baik konsep dan esensi pemberlakuannya. Dengan adanya kolaborasi lebih dari seorang guru di dalam kelas, maka proses observasi terhadap siswa menjadi lebih intens. Catatan khusus terhadap perilaku, ketidakbisaan, kesulitan siswa akan terekam dengan baik, bersama dengan itu, teknik pengajaran pun akan dapat dikritisi dengan baik. Dengan ini maka siswa dapat terpantau secara individual, sehingga dapat mendorong siswa untuk belajar lebih bersemangat.

Untuk dapat melakukan ini dengan baik, maka kedua guru yang berkolaborasi harus mempunyai kesamaan komitmen dan kesiapan untuk bersikap kritis dan mengkritisi. Dengan adanya lebih dari satu orang guru dalam satu kelas, akan membantu siswa bebas meminta pelayanan dalam memecahkan masalah dan mendiskusikannya tanpa adanya batasan-batasan yang biasa mereka temui dalam kegiatan belajar reguler. Tentunya guru yang terlibat dalam team teaching telah menetapkan visi yang sama sehingga tidak terjadi overlapping dalam pemberian penjelasan. Pendekatan individu lebih ditekankan untuk membantu siswa agar mereka tidak merasa takut untuk mengemukakan persoalan yang mereka hadapi.

Berdasarkan observasi di kelas X SMK Negeri 1 Robatal, pada waktu proses pembelajaran dimulai siswa tidak segera memasuki kelas dan beberapa siswa datang terlambat serta suasana kelas sangat gaduh. Saat guru menerangkan pelajaran, siswa memperhatikan tetapi sebagian siswa yang duduk di deretan

\footnotetext{
${ }^{1}$ David W. Beggs. Team Teaching Bold New Venture. (Bloomington: Indiana University Press, 1971), 16.
} 
belakang masih ramai. Ada siswa yang mengobrol dengan teman sebangkunya, bahkan ada yang mengerjakan tugas selain pelajaran matematika. Pada waktu siswa mengerjakan soal latihan, guru sesekali menghampiri dan memberi penjelasan kepada siswa yang dirasa kesulitan saat mengerjakan soal. Tetapi tindakan seperti itu tidak selalu dilakukan pada setiap siswa, karena keterbatasan waktu dan tenaga. Maka guru tidak dapat memberikan pelayanan kepada siswanya secara individual. Hal ini mengakibatkan siswa putus asa dalam menghadapi kesulitan saat mengerjakan tugas. Padahal menurut Sardiman salah satu ciri orang yang bermotivasi adalah tekun menghadapi tugas. ${ }^{2}$

Sejalan dengan pernyataan di atas, peneliti ingin mencoba melakukan perubahan dengan melaksanakan penelitian tindakan melalui team teaching guna meningkatkan motivasi siswa dalam pembelajaran di kelas dengan strategi pembelajaran kooperatif tipe belajar bersama (learning together). Dengan learning together akan memberikan semangat bagi siswa karena metode ini berwujud kelompok-kelompok yang akan bekerja sama untuk memajukan kelompok dan individu dalam pengetahuan dan keterampilan.

\section{Pembelajaran Matematika}

James dan James yang dikutip Erman Suherman mengatakan bahwa matematika adalah ilmu tentang logika mengenai bentuk, susunan, besaran dan konsep-konsep yang berhubungan satu dengan lainnya dengan jumlah yang banyak yang terbagi ke dalam tiga bidang, yaitu aljabar, analisis dan geometri. ${ }^{3}$ Sedangkan menurut Russefendi yang dikutip oleh Erman Suherman matematika terbentuk sebagai hasil pemikiran manusia yang berhubungan dengan ide proses dan penalaran. Sesuai dengan pengertian dan karakter matematika di atas, matematika merupakan ilmu pengetahuan sebagai sarana berpikir yang meliputi penalaran dan logika, serta objeknya yang bersifat abstrak.

Pembelajaran merupakan upaya penataan lingkungan yang memberikan nuansa agar program belajar tumbuh dan berkembang secara optimal. Menurut salah satu hal yang harus diperhatikan dalam kegiatan pembelajaran adalah mengatur suasana kelas agar siswa siap belajar. Menurut Sriyanto, tugas guru bukan lagi aktif mentransfer pengetahuan tetapi menciptakan kondisi belajar dan merencanakan jalannya pembelajaran dengan materi yang sesuai bagi siswa sehingga siswa memperoleh pengalaman belajar yang optimal. ${ }^{4}$ Sesuai dengan pengertian di atas, dalam kegiatan pembelajaran pasti ada kaitannya dengan siswa belajar. Dalam pembelajaran di sekolah, guru hendaknya memilih dan menggunakan strategi, pendekatan, metode dan teknik yang banyak melibatkan siswa aktif dalam belajar.

Menurut Erman Suherman belajar merupakan pengembangan pengetahuan baru, keterampilan dan sikap ketika seorang individu berinteraksi dengan informasi dan lingkungan. Belajar matematika menurut Erman Suherman

\footnotetext{
${ }^{2}$ Sardiman. Interaksi dan Motivasi Belajar. (Jakarta: Rajawali Pers, 2001), 83.

${ }^{3}$ Erman Suherman dkk. Strategi Pembelajaran Matematika Kontemporer. (Bandung: UPI, 2003), 16.

${ }^{4}$ Ibid. 47.
} 
merupakan proses dimana siswa secara aktif mengkonstruksi pengetahuan matematika. ${ }^{5}$

Fokus utama belajar matematika adalah memberdayakan siswa untuk berpikir mengkonstruksi pengetahuan matematika yang telah dikemukakan oleh ahli-ahli sebelumnya. Dengan demikian, pembelajaran matematika dapat diartikan sebagai suatu rangkaian kegiatan yang melibatkan guru dan siswa, dimana kegiatan guru ditujukan kepada siswa dalam menyampaikan pengetahuan dan keterampilan serta membimbing dan melatih siswa agar belajar tentang matematika.

\section{Motivasi Belajar}

Motivasi berasal dari Bahasa Inggris yaitu motivation. Motif adalah dorongan atau stimulus yang datang dari dalam batin atau hati orang yang menggerakkan perilaku sadarnya untuk memenuhi kebutuhan untuk mencapai sasaran yang ditujunya. ${ }^{6}$

Menurut Ngalim Purwanto, motivasi adalah pendorongan, suatu usaha yang disadari untuk mempengaruhi tingkah laku seseorang agar ia tergerak hatinya untuk bertindak melakukan sesuatu sehingga mencapai hasil atau tujuan tertentu. ${ }^{7}$ Pendapat Ivor. K Devis menyatakan bahwa motivasi merupakan kekuatan tersembunyi didalam diri kita untuk berkelakuan dan bertindak dengan cara yang khas. $^{8}$

Oemar Hamalik menyatakan bahwa motivasi belajar siswa ada 2 yaitu motivasi intrinsik dan motivasi ekstrinsik. ${ }^{9}$

1) Motivasi intrinsik

Motivasi intrinsik adalah motivasi yang tercakup dalam situasi belajar yang bersumber dari kebutuhan dan tujuan-tujuan siswa sendiri. Motivasi ini timbul tanpa pengaruh luar. Motivasi yang berasal dari dalam dapat berupa: keinginan untuk berhasil, keinginan untuk memperoleh pengetahuan, keinginan untuk terampil serta keinginan untuk mengembangkan pengetahuan yang dimiliki.

Thornburgh dalam Elida Prayitno, mengemukakan bahwa motivasi intrinsik adalah kegiatan bertindak yang disebabkan faktor pendorong diri dalam diri individu. Elida Prayitno, selanjutnya menjelaskan di dalam proses belajar, siswa yang bermotivasi secara interinsik dapat dilihat dari kegiatannya yang tekun dalam mengerjakan tugas-tugas belajar karena merasa perlu dan ingin mencapai tujuan belajar yang sebenarnya. ${ }^{10}$

2) Motivasi ekstrinsik

Motivasi ekstrinsik adalah motivasi yang berasal dari luar atau motivasi yang timbul dari pengaruh luar. Motivasi yang berasal dari luar berupa: adanya keinginan memperoleh penghargaan, adanya persaingan antar teman dan adanya

\footnotetext{
5 Ibid.76.

${ }^{6}$ Harjana, Agus, Kiat Sukses Studi di Perguruan Tinggi. (Yogyakarta: Kanisius, 1994), 21.

${ }^{7}$ Purwanto, Ngalim. Psikologi Pendidikan. (Bandung : Rosda Karya,1990), 71.

8 Davis, Ivor K. Pengelolaan Belajar. (Jakarta: Rajawali Pers, 1991),217.

9 Oemar Hamalik. Proses Belajar Mengajar. (Jakarta: Bumi Aksara, . 2005),162.

10Prayitno, Elida. Motivasi dalam Belajar. (Jakarta: Depdikbud, 1989), 11.
} 
dorongan dari guru. Motivasi ekstrinsik adalah motif-motif yang aktif dan berfungsinya karena adanya motivasi dari luar. ${ }^{11}$

Motivasi ekstrinsik ini tetap diperlukan di sekolah sebab pengajaran di sekolah tidak semuanya menarik minat siswa atau sesuai dengan kebutuhan siswa. Berdasarkan definisi motivasi di atas dapat disimpulkan bahwa motivasi adalah dorongan pada diri seseorang untuk bertindak atau melakukan sesuatu pekerjaan baik yang timbul dari diri orang itu sendiri ataupun dari luar yang berkaitan erat dengan tujuan dan cita-cita yang hendak dicapai dalam kaitannya dengan belajar. Motivasi dapat dibedakan sebagai keseluruhan daya penggerak dalam diri siswa yang akan menimbulkan kegiatan belajar dan memberikan arah pada kegiatan belajar.

\section{Fungsi Motivasi Belajar}

Dalam kaitanya dengan belajar, motivasi merupakan daya penggerak untuk melakukan kegiatan belajar. Individu yang memiliki motivasi yang tinggi dalam belajarnya akan berusaha melaksanakan kegiatan belajar tersebut dengan senang hati dan selalu bergairah untuk terus belajar sehingga proses belajar akan berlangsung lebih efektif dan efisien. Oleh sebab itu, motivasi belajar harus selalu dijaga dan dipelihara, baik oleh guru maupun oleh siswa sendiri.

Senada dengan hal itu Ahmad Rohani menjelaskan fungsi motivasi belajar bagi siswa, sebagai berikut: ${ }^{12}$

1) Memberi semangat dan mengaktifkan siswa supaya tetap berminat dan siaga. Tanpa motivasi tidak akan timbul perbuatan seperti perbuatan belajar.

2) Memusatkan perhatian siswa pada tugas-tugas tertentu yang berhubungan dengan pencapaian tujuan belajar.

3) Membantu memenuhi kebutuhan akan hasil jangka pendek dan jangka panjang.

Motivasi belajar juga penting diketahui oleh seorang siswa, pengetahuan dan pemahaman tentang motivasi belajar mendorong timbulnya kelakuan dan mempengaruhi serta mengubah kelakuan siswa. Jadi menurut Oemar Hamalik fungsi motivasi itu adalah: ${ }^{13}$

1) Mendorong timbulnya kelakuan atau perbuatan. Tanpa motivasi tidak akan timbul suatu perbuatan seperti belajar.

2) Sebagai pengarah, artinya mengarahkan perbuatan kepada pencapaian tujuan yang diinginkan.

3) Sebagai penggerak, ia berfungsi sebagai mesin mobil. Besar kecilnya motivasi akan menentukan cepat atau lambatnya suatu pekerjaan.

Motivasi belajar bagi peserta didik secara tidak langsung mempengaruhi gaya belajar siswa. Apabila motivasi belajar siswa menurun maka gaya belajar siswa juga akan cenderung jelek dan secara tidak langsung juga akan berpengaruh terhadap pencapaian prestasi belajar siswa dan kreativitas siswa. Di sini peranan guru sangat penting sekali terhadap peningkatan motivasi belajar siswa. Guru merupakan faktor dominan terhadap tinggi dan rendahnya motivasi siswa terhadap proses pembelajaran yang sedang berlangsung. Guru merupakan komponen yang utama pada dunia pendidikan, karena secara langsung

\footnotetext{
${ }^{11}$ Sardiman. Interaksi dan Motivasi Belajar. (Jakarta: Rajawali Pers, 2001), 176.

12 Ahmad Rohani. Pengelolaan Pengajaran. (Jakarta: Rhineka Cipta, 1990),11.

13 Oemar Hamalik. Proses Belajar Mengajar. (Jakarta: Bumi Aksara, 2005),161.
} 
berinteraksi dengan peserta didik. Sehingga pengaruh guru terhadap peningkatan motivasi siswa sangat besar.

Dengan motivasi orang akan terdorong untuk bekerja mencapai sasaran dan tujuannya karena yakin dan sadar akan kebaikan, kepentingan dan manfaatnya. Bagi siswa, motivasi ini sangat penting karena dapat menggerakkan perilakunya kearah yang positif sehingga mampu menghadapi segala tuntutan, kesulitan serta menanggung resiko dalam studinya.

Menurut M. Dalyono motivasi dapat menentukan baik tidaknya dalam mencapai tujuan sehingga semakin besar motivasinya akan semakin besar kesuksesan belajarnya. Motivasi sebagai faktor batin berfungsi menimbulkan, mendasari, dan mengarahkan perbuatan belajar. Seorang yang besar motivasinya akan giat berusaha, tampak gigih, tidak mau menyerah, serta giat membaca untuk meningkatkan prestasi serta memecahkan masalah yang dihadapinya. ${ }^{14}$

Sebaliknya mereka yang motivasinya rendah, tampak acuh tak acuh, mudah putus asa, perhatiannya tidak tertuju pada pelajaran yang akibatnya mereka akan mengalami kesulitan belajar. Motivasi menggerakkan organisme mengarahkan tindakan serta memilih tujuan belajar yang dirasa paling berguna bagi kehidupan individu. Dengan mempelajari motivasi maka akan ditemukan mengapa individu berbuat sesuatu tetapi motivasi individu tidak dapat diamati secara langsung. Sedangkan yang dapat diamati adalah manifestasi dari motivasi itu dalam bentuk tingkah laku yang nampak pada individu setidaknya akan mendekati kebenaran apa yang menjadi motivasi individu yang bersangkutan.

Dengan demikian bahwa fungsi motivasi dalam belajar sangat besar karena dapat mendorong individu untuk menyelesaikan tugas atau kegiatan dengan hasil yang lebih baik. Dengan motivasi yang tinggi seseorang akan melakukan kegiatan belajar dengan semangat yang tinggi, penuh percaya diri, terarah dan akan selalu bergairah/semangat untuk selalu belajar dan belajar sampai didapat prestasi yang maksimal.

\section{Cara Membangkitkan Motivasi Belajar}

Ada beberapa cara untuk menumbuhkan motivasi dalam kegiatan belajar siswa di sekolah di antaranya yaitu memberi nilai-nilai, hadiah, saingan/kompetensi, kerja kelompok, mengetahui hasil, pujian dan tujuan yang diakui. Motivasi juga timbul karena adanya kebutuhan, tujuan yang ingin dicapai dan lingkungan.

Salah satu cara membangkitkan motivasi belajar pada siswa adalah dengan menunjukkan kepada siswa bahwa keterampilan yang mereka pelajari itu sangat diperlukan oleh mereka dalam rangka belajarnya. Sementara itu Sardiman berpendapat bahwa menumbuhkan kesadaran kepada siswa agar merasakan pentingnya tugas dan menerimanya sebagai tantangan sehingga bekerja dengan mempertaruhkan harga diri, adalah sebagai salah satu bentuk motivasi yang cukup penting. Motivasi perannya yang khas adalah dalam menumbuhkan gairah merasa senang dan semangat untuk belajar.

Menurut Harjimat mengemukakan bahwa aktivitas belajar siswa dalam proses pembelajaran yang komplek dan bervariasi serta mencakup seluruh aspek dalam

14 Ibid, 235. 
diri individu yang dilakukan secara sadar maupun tidak disadari, menunjukkan adanya motivasi belajar yang tinggi pada diri peserta didik tersebut.

Dari beberapa uraian di atas mejadi jelas bahwa dengan adanya sikap dan aktivitas belajar siswa menujukkan adanya kegairahan belajar yang tinggi sehingga prestasi belajarnya meningkat dan kegairahan ini dapat diartikan sebagai motivasi belajar.

\section{Pembelajaran Kooperatif}

Pembelajaran kooperatif mencakup suatu kelompok kecil siswa yang belajar sebagai sebuah tim untuk menyelesaikan suatu masalah, menyelesaikan suatu tugas, atau mengerjakan sesuatu untuk mencapai tujuan bersama. Pembelajaran kooperatif menekankan pada kehadiran teman sebaya yang berinteraksi antar sesamanya sebagai sebuah tim dalam menyelesaikan atau membahas suatu masalah.

Ada beberapa metode pembelajaran kooperatif yang telah banyak dilakukan dan dievaluasi seperti berikut:

a. STAD (Student Teams Achievement Division)

Menurut Robert E. Slavin, STAD adalah metode pembelajaran kooperatif untuk mengelompokan kemampuan campur yang melibatkan pengakuan tim dan tanggung jawab kelompok untuk pembelajaran individu anggota. Dalam STAD siswa ditempatkan dalam tim belajar beranggotakan empat atau lima orang yang merupakan campuran menurut tingkat kinerja, jenis kelamin dan suku. Guru menyajikan pelajaran, kemudian siswa belajar didalam tim mereka untuk memastikan seluruh anggota tim telah menguasai pelajaran tersebut. ${ }^{15}$

b. Team-Games Tournament (TGT)

Menurut Robert E. Slavin, TGT hampir sama dengan STAD, namun dalam TGT tidak digunakan kuis atau silang tanya, melainkan menggunakan turnamen. Siswa memainkan permainan dengan anggota-anggota tim lain untuk memperoleh tambahan nilai untuk skor tim mereka. TGT terdiri dari empat langkah, yaitu identifikasi masalah, pembahasan masalah dalam kelompok, presentasi hasil bahasan kelompok (turnamen) dan penguatan guru. ${ }^{16}$

c. Jigsaw

Menurut Robert E. Slavin, teknik mengajar jigsaw dikembangkan oleh Aronson, sebagai metode pembelajaran kooperatif. Dalam tekhnik ini, guru memperhatikan skemata atau latar belakang pengalaman siswa dan membantu siswa mengaktifkan skemata ini agar bahan pelajaran menjadi lebih bermakna. Selain itu, siswa bekerja dengan sesama siswa dalam suasana gotong royong dan mempunyai banyak kesempatan untuk mengolah informasi dan meningkatkan keterampilan berkomunikasi.

Teknik ini serupa dengan pertukaran kelompok dengan kelompok, namun ada satu perbedaan penting, yakni tiap siswa mengajarkan sesuatu. Ini merupakan alternatif menarik bila ada materi belajar yang bisa disegmentasikan atau dibagibagi dan bila bagian-bagianya harus diajarkan secara berurutan. Tiap siswa

15 Robert E. Slavin. Cooperative Learning Teori, Riset dan Praktik. (Bandung: Nusa, 2017), 58.

16 Ibid, 129. 
mempelajari sesuatu yang bila digabungkan dengan materi yang dipelajari oleh siswa lain, membentuk kumpulan pengetahuan atau keterampilan yang padu.

d. Penelitian Kelompok atau Group Investigation

Menurut Robert E. Slavin penelitian kelompok atau group investigation merupakan suatu rencana organisasi kelas umum. Didalam tatanan ini siswa bekerja dalam kelompok-kelompok kecil menggunakan diskusi kelompok, dan perencanaan serta proyek kooperatif. Dalam metode ini, siswa membentuk kelompoknya sendiri yang terdiri dari empat sampai enam anggota.

Setelah memilih beberapa subtopik dari sebuah bab yang sedang dipelajari seluruh kelas, kelompok-kelompok tersebut melakukan diskusi dan membuat laporan kelompok. Setiap kelompok kemudian membuat presentasi atau peragaan untuk mengkomunikasikan temannya kepada seluruh kelas.

e. Belajar Bersama atau Learning Together

Menurut Robert E. Slavin, belajar bersama atau learning together adalah model pembelajaran kooperatif yang dikembangkan oleh Johnson dan Johnson. Metode ini melibatkan siswa yang bekerja dalam kelompok-kelompok beranggota empat atau lima orang berbeda untuk menangani tugas tertentu. Kelompokkelompok itu menyerahkan satu hasil kelompok dan menerima pujian dan ganjaran berdasarkan pada hasil kelompok tersebut. Metode ini menekankan pada kegiatan-kegiatan pembinaan kerjasama tim sebelum siswa mulai bekerja sama dan melakukan diskusi terjadwal didalam kelompok tentang seberapa jauh mereka berhasil dalam bekerja sama. ${ }^{17}$

\section{Team Teaching}

a. Pengertian dan Tujuan Team Teaching. Team Teaching pada dasarnya ialah metode mengajar dua orang guru atau lebih bekerja sama mengajar sebuah kelompok siswa. Jadi, kelas dihadapi beberapa guru. Menurut Redja Mudyahardjo meskipun mengajar pada dasarnya adalah suatu kegiatan perorangan, dalam arti bahwa setiap guru harus bertanggung jawab terhadap tugas-tugas profesionalnya, tetapi kerja tim adalah sangat penting terutama pada tingkat pendidikan menengah. Para guru tersebut bersama-sama mempersiapkan, melaksanakan dan mengevaluasi hasil belajar siswa.

Pelaksanaan belajarnya dapat dilakukan secara bergilir dengan metode ceramah atau bersama-sama dengan metode diskusi panel. Martadi menjelaskan, team teaching adalah pembelajaran satu mata pelajaran kepada sekelompok siswa dalam satu kelas, oleh dua orang guru atau lebih, bersama, bekerja sama, berkolaborasi antara guru dan siswa dalam waktu pertemuan yang sama. Team teaching juga dikenal dengan istilah mengajar dalam satu tim (lebih dari satu orang), pengajaran beregu, atau collaborative teaching.

Team Teaching menurut Ira J. Singer adalah, "Team teaching may be defined as an arrangement whereby two or more teachers, with or without teacher aides, cooperatively plan, instruct and evaluate one or more class groups in an appropriate instructional space and given length of time, so as to take advantage of the special competencies of the team members".18

17 Ibid, 289.

${ }^{18}$ David W. Beggs. Team Teaching Bold New Venture. (Bloomington: Indiana University Press, 1971), 68. 
Sementara itu menurut Jamal Ma'mur Asmani tujuan pelaksanaan team teaching adalah untuk mengefektifkan proses pembelajaran. Hal ini didasarkan pada konsep dan anggapan bahwa jika proses pembelajaran dipandu oleh sebuah tim dan tidak hanya satu orang guru, maka pendampingan terhadap belajar siswa menjadi lebih maksimal. Selain itu, masing-masing guru dapat saling melengkapi kekurangan dan kemampuan masing-masing. Tujuan utama penerapan team teaching adalah untuk meningkatkan kualitas hasil proses pembelajaran. ${ }^{19}$

b. Jenis-jenis Team Teaching. Terdapat beberapa jenis metode Team Teaching yang dijelaskan oleh Soewalni S. yang dikutip oleh Jamal Ma'mur Asmani, yakni: ${ }^{20}$ (1) Semi Team Teaching. Terdapa tiga variasi dalam pelaksanaan semi team teaching: (a) Sejumlah guru mengajar mata pelajaran yang sama di kelas yang berbeda, perencanaan materi dan metode disepakati bersama; (b) Satu mata pelajaran disajikan oleh sejumlah guru secara bergantian dengan pembagian tugas, materi dan evaluasi oleh guru masing-masing; (c) Satu mata pelajaran disajikan oleh sejumlah guru dengan mendesain siswa secara berkelompok. (2) Team Teaching Penuh. Variasi team teaching penuh: (a) Pelaksanaan bersama, seorang guru sebagai penyaji atau menyampaikan informasi, seorang guru membimbing diskusi kelompok atau membimbing latihan individual; (b) Anggota tim secara bergantian menyajikan topik/atau materi. Diskusi/tanya jawab dibimbing secara bersama dan saling melengkapi jawaban dari anggota tim; (c) Seorang guru (senior) menyajikan langkah-langkah dalam latihan, observasi, praktik, dan informasi seperlunya. Kelas dibagi dalam kelompok, setiap kelompok dipandu seorang guru (tutor, fasilitator, mediator). Akhir pembelajaran masing-masing kelompok menyajikan laporan (lisan/tertulis) dan ditanggapi bersama serta disimpulkan bersama.

c. Model-model Team Teaching. Ada beberapa model team teaching menurut Jamal Ma'mur Asmani. Di antaranya adalah team teaching model tradisional, yaitu sebuah model di mana dua orang guru mengajar dalam satu kelas. Mereka berbagi tanggung jawab yang sama dalam mengajar para siswa dan secara aktif terlibat dalam proses pembelajaran selama jam pembelajaran berlangsung. Misalnya salah satu guru melaksanakan pembelajaran, sedangkan guru lain menulis atau membuat catatan di papan tulis. ${ }^{21}$ Model-model yang lebih menantang dan signifikan dapat meningkatkan mutu pendidikan antara lain: (1) Supported Instruction. Supported Instruction adalah bentuk team teaching dengan salah seorang guru menyampaikan materi pelajaran. Sedangkan guru lainnya melakukan kegiatan tindak lanjut dari materi yang telah disampaikan rekan satu timnya tersebut; (2) Parallel Instruction. Parallel Instruction adalah sebuah bentuk team teaching yang pelaksanaannya dengan membagi siswa menjadi dua kelompok. Sedangkan tiap-tiap guru dalam tim bertanggung jawab untuk mengajar masingmasing kelompok tersebut; (3) Differentiated Split Class. Differentiated split class adalah team teaching yang dilaksanakan dengan cara membagi siswa ke dalam dua kelompok berdasarkan tingkat pencapaiannya. Kemudian salah seorang guru melakukan pengajaran remedial terhadap siswa yang tingkat pencapaian kompetensinya kurang atau tidak mencapai KKM. Sedangkan guru yang lain

\footnotetext{
19 Jamal Ma'mur Asmani. Pengenalan dan Pelaksanaan Lengkap Micro Teaching \& Team Teaching. (Yogyakarta: Diva Press, 2017), 50.

20 Ibid, 52.

21 Ibid, 57.
} 
melakukan pengayaan kepada mereka yang telah mencapai atau melampaui standard minimal KKM; (4) Monitoring Teacher. Monitoring teacher adalah team teaching yang dilaksanakan dengan cara sebagai berikut. Salah seorang guru melakukan pembelajaran di kelas, sedangkan yang lainnya berkeliling untuk memonitor perilaku dan kemajuan siswa.

d. Tahapan-tahapan Team Teaching. Menurut Baharuddin dan Esa Nur Wahyuni team teaching direncanakan oleh dua atau lebih guru sebagai tim pengajar, sehingga guru dapat merencanakan pengajaran bersama, berbagi sumber belajar dan menggabungkan siswa. ${ }^{22}$ Tahapan pembelajaran dengan team teaching menurut Jamal Ma'mur Asmani adalah sebagai berikut: 23

(1) Perencanaan pembelajaran. (a) Perencanaan pembelajaran disusun bersama. Perencanaan pembelajaran atau rencana pelaksanaan pembelajaran (RPP) harus disusun secara bersama-sama oleh setiap guru yang tergabung dalam team teaching. Agar para guru tersebut memahami tentang semua yang tercantum dalam isi RPP sehingga guru mengetahui alur proses pembelajaran dan tidak kehilangan arah pembelajaran; (b) Metode pembelajaran ditetapkan bersama. Selain RPP yang harus disusun bersama oleh tim, metode yang akan digunakan dalam proses pembelajaran team teaching juga harus ditetapkan bersama. Penetapan metode secara bersama ini dilakukan agar setiap guru mengetahui alur dan proses pembelajaran dan tidak kehilangan arah pembelajaran; (c) Partner team teaching memahami materi dan isi pembelajaran. Guru sebagai partner dalam team teaching bukan hanya harus mengetahui tema dari materi yang akan disampaikan kepada siswa saja, melainkan harus bersama-sama mengetahui dan memahami isi dari materi pelajaran tersebut. Hal ini agar keduanya dapat saling melengkapi kekurangan pengetahuan yang ada dalam dalam diri masing-masing. Selain itu sangat terasa manfaatnya dalam penyampaian materi pada siswa dan menjawab pertanyaan-pertanyaan siswa atas penjelasan guru; (d) Pembagian peran dan tanggung jawab secara jelas. Pembagian peran dan tanggung jawab masing-masing guru harus dibicarakan secara jelas ketika merencanakan proses pembelajaran yang akan dilaksanakan. Tujuannya agar ketika proses pembelajaran berlangsung, para guru mengetahui perandan tanggung jawab masing-masing.

(2) Pelaksanaan pembelajaran. Siswa harus aktif selama proses pembelajaran berlangsung. Apabila menemui kesulitan segera ditanyakan kepada guru. Jadi siswa tidak mudah menyerah dalam menghadapi kesulitan. Surya Dharma menjelaskan hal-hal yang harus diperhatikan dalam pelaksanaan metode team teaching, yaitu: ${ }^{24}$ (a) Harus ada program pelajaran yang disusun bersama oleh tim tersebut, sehingga betul-betul jelas dan terarah sesuai dengan tugas masingmasing dalam tim tersebut; (b) Membagi tugas tiap topik kepada guru tersebut, sehingga masalah bimbingan pada siswa terarah dengan baik; (c) Harus dicegah jangan sampai terjadi jam bebas akibat ketidakhadiran seorang guru anggota tim.

3) Tahap evaluasi. Menurut Jamal Ma'mur Asmani pada tahap evaluasi, ada dua objek yang harus dilakukan proses evaluasi, yaitu guru dan siswa. Berikut

\footnotetext{
${ }^{22}$ Baharuddin \& Esa Nur Wahyuni. Teori Belajar dan Pembelajaran. (Jakarta: Ar-Ruzz Media, 2007), 145.

${ }^{23}$ Jamal Ma'mur Asmani. Pengenalan dan Pelaksanaan Lengkap MicroTeaching \& Team Teaching. (Yogyakarta: Diva Press, 2017) 58.

${ }^{24}$ Surya Dharma. Strategi Pembelajaran dan Pemilihannya. (Jakarta: Depdiknas, 2017),29.
} 
penjelasan dan cara melakukan evaluasi terhadap guru dan siswa. (a) Evaluasi guru. Evaluasi guru selama proses pembelajaran dilaksanakan oleh partner tim setelah jam pelajaran berakhir. Evaluasi dilakukan dengan cara memberi kritikankritikan dan saran yang membangun untuk perbaikan proses pembelajaran selanjutnya. Guru yang diberi saran harus menerima dengan baik, karena itulah kelebihan team teaching. Evaluasi dilaksanakan di luar ruang kelas untuk mengaja image guru di hadapan siswa. (b) Evaluasi siswa. Evaluasi siswa mencakup pembuatan soal evaluasi dan merencanakan metode evaluasi, yang semuanya dilaksanakan secara bersama-sama oleh guru team teaching. Atas kesepakatan bersama, para guru anggota tim harus membuat soal-soal evaluasi yang akan diberikan kepada siswa dimana penentuan bentuk evaluasi lisan atau tulisan, baik pilihan ganda maupun uraian atau campuran keduanya.

Perencanaan metode evaluasi siswa mencakup pembagian peran dan tanggung jawab setiap guru dalam tim dalam pelaksanaan evaluasi serta pembagian pos-pos pengawasan.

e. Efektivitas Team Teaching

Menurut Jamal Ma'mur Asmani efektivitas pelaksanaan team teaching pada dasarnya sangat tergantung pada pemahaman tiap-tiap guru tentang konsep dasar team teaching. Hal ini untuk menghindari terjadinya kesalahpahaman antara sesama anggota tim. Pelaksanaan team teaching akan efektif jika benar-benar sesuai engan konsep yang ada. Sebab anak didik akan mendapatkan materi yang lengkap. Setiap guru dalam proses pembelajaran memberikan materi pelajaran sesuai dengan kompetensinya masing-masing. ${ }^{25}$

Dengan demikian efektivitas program pembelajaran dengan sistem team teaching tergantung pada kinerja para guru yang terlibat dalam team teaching. Sedangkan kinerja tersebut merupakan hasil dari pemahaman mereka terhadap konsep dasar tentang strategi team teaching.

Oleh sebab itu, para guru hendaknya betul-betul memahami konsep dasar strategi pembelajaran team teaching. para guru anggota tim harus melaksanakan tugas mengajar secara maksimal dan sistematis sebagaimana tugas dan kewajiban anggota yang lain. Setiap guru harus saling mendukung dan mengisi celah-celah yang memungkinkan terjadinya black hole dalam proses pembelajaran. Black hole yang tercipta akibat sikap dan kompetensi guru yang tidak sesuai dengan pola pembelajaran, akan membuat proses pembelajaran menjadi terputus.

\section{Jenis Penelitian}

Jenis penelitian yang dilaksanakan adalah penelitian tindakan kelas (PTK) yang dilakukan secara kolaboratif dan partisipatif. Kolaboratif artinya peneliti berkolaborasi atau bekerja sama dengan guru matematika kelas X SMK Negeri 1 Robatal Kabupaten Sampang. Sedangkan partisipatif artinya dalam penelitian ini memerlukan partisipasi aktif dari siswa kelas X SMK Negeri 1 Robatal Kabupaten Sampang.

\section{Teknik Pengumpulan Data}

Teknik yang digunakan dalam pengumpulan data adalah sebagai berikut:

\footnotetext{
25 Jamal Ma'mur Asmani. Pengenalan dan Pelaksanaan Lengkap Micro Teaching \& Team Teaching. (Yogyakarta: Diva Press, 2017), 89.
} 


\section{Observasi}

Observasi dilakukan oleh teman sejawat peneliti dengan cara melakukan pengamatan dan pencatatan aktivitas siswa, guru 1, dan guru 2 selama proses pembelajaran matematika dengan team teaching. Observasi dilakukan dengan menggunakan lembar observasi yang telah dipersiapkan.

2. Catatan lapangan

Catatan lapangan adalah catatan tertulis tentang apa yang didengar, dialami, dan dipikirkan dalam rangka pengumpulan data. Catatan lapangan digunakan untuk mencatat hal-hal yang terjadi selama proses pembelajaran di kelas, seperti kegiatan yang dilakukan guru dan siswa dalam pembelajaran.

3. Angket

Angket adalah alat pengumpulan data secara tertulis yang berisi daftar pernyataan yang disusun secara khusus dan digunakan untuk menggali dan menghimpun keterangan dan/atau informasi sebagaimana dibutuhkan. Dalam penelitian ini angket yang digunakan adalah angket motivasi.

\section{Teknik Analisis Data}

Data yang terkumpul berupa hasil angket, observasi. Data yang diperoleh dianalisis secara deskriptif untuk mengetahui pelaksanaan dan hambatanhambatan yang terjadi selama pembelajaran. Tahapan-tahapan dalam proses analisis data adalah dengan reduksi data, penyajian data, dan penarikan kesimpulan.

Adapun secara lebih rinci analisis datanya adalah sebagai berikut:

1. Analisis data hasil observasi

Lembar observasi untuk mengetahui keterlaksanaan pembelajaran dengan menggunakan metode team teaching yang menciptakan lingkungan belajar yang efektif, dengan cara menggunakan unsur yang ada pada siswa, guru dan lingkungan belajarnya melalui interaksi yang terjadi di dalam kelas.

Skala yang digunakan dalam lembar observasi ini menggunakan skala Guttman, observer membubuhkan tanda cek $(\sqrt{ })$ pada langkahlangkah pembelajaran yang terlaksana pada kolom "ya" dan "tidak". Dan dari setiap aspek yang terlaksana (pada kolom "ya") diberi skor 1, jika tidak terlaksana (pada kolom "tidak") diberi skor 0. Kemudian dihitung persentase keterlaksanaannya, dengan rumus:

$$
\begin{gathered}
\mathrm{F} \\
\mathrm{P}=-\mathrm{--} \times 100 \% \\
\mathrm{~A}
\end{gathered}
$$

Keterangan:

$\mathrm{P}=$ persentase keterlaksanaan pembelajaran

$\mathrm{F}=$ jumlah skor keterlaksanaan pembelajaran

A = jumlah skor maksimal keterlaksanaan pembelajaran

2. Analisis catatan lapangan

Catatan lapangan dianalisis dengan mendeskripsikan aktivitas selama pembelajaran berlangsung.

3. Analisis data dari pengisian angket motivasi 
Analisis hasil dari pengisian angket motivasi belajar siswa dilakukan dengan memberi skor pada masing-masing butir pada lembar pengisian angket. Setiap jawaban diberi skor sebagai berikut:

Tabel 1 Pedoman Skor Angket Motivasi Belajar Matematika

\begin{tabular}{|c|c|c|c|c|}
\hline \multirow{2}{*}{ Pernyataan } & \multicolumn{4}{|c|}{ Skor Jawaban } \\
\cline { 2 - 5 } & Selalu & Sering & Kadang-kadang & Tidak Pernah \\
\hline$(+)$ & 4 & 3 & 2 & 1 \\
\hline$(-)$ & 1 & 2 & 3 & 4 \\
\hline
\end{tabular}

Dari tabel di atas, hasil angket siswa dianalisis melalui langkah-langkah senbagai berikut:

1) Masing-masing butir angket dikelompokkan sesuai dengan aspek-aspek yang diamati.

2) Masing-masing butir dihitung jumlah skornya sesuai dengan aspek yang diamati. Cara menghitung persentase skor aspek sebagai berikut:

$$
P=\frac{F}{A} \times 100 \%
$$

Keterangan:

$\mathrm{P}=$ persentase motivasi

$\mathrm{F}=$ jumlah skor perolehan siswa

A = jumlah skor maksimal

3) Jumlah skor yang diperoleh kemudian dikualifikasi untuk menentukan seberapa besar motivasi siswa dalam mengikuti proses pembelajaran. Berikut tabel kualifikasi hasil persentase skor analisis:

Tabel 2. Kualifikasi Persentase Skor Angket Motivasi Belajar

\begin{tabular}{|c|c|}
\hline Persentase & Kriteria \\
\hline $75,00 \% \leq X \leq 100 \%$ & Tinggi \\
\hline $50,00 \% \leq X \leq 74,99 \%$ & Sedang \\
\hline $25,00 \% \leq X \leq 49,99 \%$ & Rendah \\
\hline
\end{tabular}

Pelaksanaan penelitian tindakan kelas pada siklus I dan siklus II meliputi empat tahapan yaitu perencanaan, pelaksanaan tindakan, observasi dan refleksi. Deskripsi penelitian tindakan kelas tentang pembelajaran matematika dengan team teaching siklus I dan siklus II adalah sebagai berikut:

\section{Pelaksanaan Tindakan Siklus I}

\section{a. Perencanaan}

Pada langkah perencanaan, guru 1 dan guru 2 membuat rencana tindakan yang akan dilaksanakan dalam penelitian, yaitu: (1) Menyusun Rencana Pelaksanaan Pembelajaran. Rencana pelaksanaan pembelajaran (RPP) disusun 
bersama oleh guru 1 dan guru 2 dengan karakteristik pembelajaran menggunakan team teaching yang difokuskan pada motivasi belajar matematika siswa; (2) Menetapkan Metode Pembelajaran. Strategi yang digunakan yaitu dengan strategi pembelajaran koopertif tipe belajar bersama (learning together). Guru 1 dan guru 2 menetapkan daftar anggota kelompok siswa, yakni tiap kelompok terdiri dari 4 siswa dengan kemampuan yang heterogen berdasarkan nilai hasil ulangan sebelumnya. Materi yang diajarkan pada pertemuan pertama yaitu bentuk umum persamaan kuadrat dan pada pertemuan kedua yaitu menyelesaikan persamaan kuadrat dengan cara memfaktorkan; (3) Menyiapkan Media. Media yang akan digunakan dalam proses pembelajaran yaitu teaching material, buku paket dan spidol; (4) Menyusun Lembar Observasi. Lembar observasi disusun berdasarkan rancangan pelaksanaan pembelajaran yang telah dibuat dan digunakan untuk mencatat hasil pengamatan selama pelaksanaan proses pembelajaran. Hal-hal yang diobservasi yaitu: perencanaan pembelajaran, pelaksanaan pembelajaran yang meliputi kegiatan awal pembelajaran, kegiatan inti pembelajaran, dan penutup, serta refleksi. Disertakan pula pada lembar observasi berupa kolom catatan dan hambatan. Lembar observasi diisi oleh rekan sejawat peneliti; dan (5) Angket Motivasi Belajar Siswa. Angket motivasi belajar siswa disusun untuk mengetahui motivasi belajar matematika siswa setelah pelaksanaan team teaching.

\section{Pelaksanaan Tindakan}

Pada tahap ini guru 1 dan guru 2 melaksanakan tindakan sesuai dengan rancangan pelaksanaan pembelajaran (RPP) yang telah disusun bersama oleh guru 1 dan guru 2. Selama pembelajaran berlangsung, pengamatan dilakukan oleh teman sejawat. Pada siklus I pembelajaran dilaksanakan dalam dua kali pertemuan. Pertemuan pertama membahas tentang bentuk umum persamaan kuadrat. Pertemuan kedua membahas tentang menyelesaikan persamaan kuadrat dengan cara memfaktorkan.

\section{Hasil Tindakan Siklus I}

Suasana kelas saat proses pembelajaran pada siklus I ini kurang mendukung terciptanya proses pembelajaran. Karena banyak siswa yang tidak memperhatikan pelajaran. Ada sebagian siswa yang terlambat masuk kelas, siswa membuat keributan di dalam kelas, sehingga guru beberapa kali meminta perhatian agar dapat menyimak pelajaran. Siswa juga kurang persiapan materi sehingga dalam memahami pelajaran masih kurang optimal, karena siswa tidak mempelajari dahulu materi yang akan diajarkan.

Dalam proses interaksi antara guru dengan siswa belum berjalan baik. Beberapa siswa terlihat enggan untuk bertanya bila ada hal yang kurang jelas. Masih ada siswa yang merasa tidak percaya diri untuk bertanya atau menjawab pertanyaan yang diberikan oleh guru. Dan kebanyakan siswa yang lain berebut minta penjelasan dari guru sehingga suasana kelas menjadi gaduh.

Dalam penyampaian materi pelajaran, hanya memberikan secara garis besarnya saja. Hal ini menyebabkan sebagian siswa menjadi kebingungan dalam berdiskusi terutama materi-materi yang memerlukan pemahaman secara khusus. Hal ini berpengaruh pada saat diskusi siswa masih banyak bertanya pada guru untuk menjelaskan materi yang belum dimengerti. Walaupun pada siklus I ini guru 
1 dan guru 2 sudah berusaha melaksanakan kegiatan pembelajaran dengan rancangan pembelajaran yang sudah dibuat, tetapi masih terdapat banyak kekurangan.

Tabel 3. Hasil Perhitungan Skor Observasi Kegiatan Pembelajaran Matematika Melalui Pelaksanaan Team Teaching Siklus I

\begin{tabular}{|c|c|c|c|c|}
\hline \multirow{2}{*}{ No } & \multirow{2}{*}{\multicolumn{2}{|c|}{ Tahap Pembelajaran Team Teaching }} & \multicolumn{2}{|c|}{ Persentase Keterlaksanaan } \\
\hline & & & Pertemuan I & $\begin{array}{c}\text { Pertemuan } \\
\text { II }\end{array}$ \\
\hline 1 & \multicolumn{2}{|c|}{ Perencanaan pembelajaran } & $100 \%$ & $100 \%$ \\
\hline \multirow[t]{3}{*}{2} & \multirow{3}{*}{$\begin{array}{l}\text { Pelaksanaan } \\
\text { Pembelajaran }\end{array}$} & Kegiatan awal & $60 \%$ & $100 \%$ \\
\hline & & Kegiatan inti & $88,89 \%$ & $100 \%$ \\
\hline & & Penutup & $66,67 \%$ & $100 \%$ \\
\hline 3 & \multicolumn{2}{|l|}{ Refleksi } & $100 \%$ & $100 \%$ \\
\hline \multicolumn{3}{|c|}{ Keterlaksanaan } & $80,95 \%$ & $100 \%$ \\
\hline \multicolumn{3}{|c|}{ Rata-rata Keterlaksanaan } & \multicolumn{2}{|c|}{$90,48 \%$} \\
\hline
\end{tabular}

Berdasarkan tabel 3 menunjukkan bahwa keterlaksanaan pembelajaran menggunakan metode team teaching pada siklus 1 sebesar 90,48\%. Pada pertemuan pertama sebesar 80,95 \% yang meliputi tahap perencanaan, tahap pelaksananaan, dan refleksi. Pada tahap perencanaan dan refleksi sudah berjalan dengan baik yakni dengan persentase keterlaksanaan sebesar 100\%. Artinya, sudah memenuhi aspek-aspek yang ditetapkan. Tetapi pada tahap pelaksanaan pembelajaran, yang meliputi kegiatan awal, kegiatan inti dan penutup berturutturut sebesar 60\%; 80,89\%; dan 66,67\%. Artinya, pelaksanaan tidak sesuai dengan rancangan pelaksanaan pembelajaran (RPP) yang telah dibuat.

Angket digunakan untuk memperkuat adanya tingkat motivasi belajar siswa dan juga digunakan sebagai bahan kajian data memperoleh informasi dan konfirmasi dalam kegiatan proses pembelajaran yang dilakukan guru, setelah penerapan pembelajaran dengan team teaching. Tabel perolehan skor motivasi belajar siswa pada halaman berikut ini:

Tabel 4. Hasil Perhitungan Skor Angket Motivasi Belajar Siswa Siklus I

\begin{tabular}{|l|c|c|}
\hline \multicolumn{1}{|c|}{ Indikator } & Persentase & Kategori \\
\hline Ketekunan menghadapi tugas & $72,34 \%$ & sedang \\
\hline Keuletan dalam menghadapi kesulitan & $78,13 \%$ & tinggi \\
\hline $\begin{array}{l}\text { Senang dan rajin, penuh semangat, dan } \\
\text { tidak cepat bosan dengan tugas-tugas } \\
\text { rutin }\end{array}$ & $78,91 \%$ & tinggi \\
\hline Dorongan untuk berprestasi & $70,31 \%$ & sedang \\
\hline $\begin{array}{l}\text { Keinginan mendalami lebih jauh materi } \\
\text { yang dipelajari }\end{array}$ & $72,66 \%$ & sedang \\
\hline $\begin{array}{l}\text { Usaha untuk berprestasi sebaik } \\
\text { Mungkin }\end{array}$ & $84,77 \%$ & tinggi \\
\hline
\end{tabular}




\begin{tabular}{|l|c|c|}
\hline Mengejar tujuan jangka panjang & $80,08 \%$ & tinggi \\
\hline $\begin{array}{l}\text { Dapat mempertanggungjawabkan } \\
\text { pendapat-pendapatnya }\end{array}$ & $73,44 \%$ & sedang \\
\hline $\begin{array}{l}\text { Minat terhadap bermacam-macam } \\
\text { Masalah }\end{array}$ & $\mathbf{7 6 , 5 6 \%}$ & tinggi \\
\hline $\begin{array}{l}\text { Senang mencari soal dan } \\
\text { Memecahkannya }\end{array}$ & $61,72 \%$ & sedang \\
\hline \multicolumn{1}{|c|}{ Persentase total } & $\mathbf{7 4 , 4 1 \%}$ & sedang \\
\hline
\end{tabular}

Berdasarkan hasil angket diperoleh data jumlah perolehan rata-rata tingkat motivasi siswa pada siklus 1 sebesar 74,41\% dengan kategori sedang. Dari hasil tersebut dibagi menjadi beberapa indikator, yaitu: (1) Ketekunan menghadapi tugas sebesar 72,34\% dengan kategori sedang; (2) Keuletan dalam menghadapi kesulitan sebesar 78,13\% dengan kategori tinggi; (3) Senang dan rajin, penuh semangat, dan tidak cepat bosan dengan tugas-tugas rutin sebesar 78,91\% dengan kategori tinggi; (4) Dorongan untuk berprestasi sebesar 70,31\% dengan kategori sedang; (5) Keinginan mendalami lebih jauh materi yang dipelajari sebesar 72,66\% dengan kategori sedang; (6) Usaha untuk berprestasi sebaik mungkin sebesar 84,77\% dengan kategori tinggi; (7) Mengejar tujuan jangka panjang sebesar 80,08\% dengan kategori tinggi; (8) Dapat mempertanggungjawabkan pendapat-pendapatnya sebesar $73,44 \%$ dengan kategori sedang; (9) Minat terhadap bermacam-macam masalah sebesar 76,56\% dengan kategori tinggi; dan (10) Senang mencari soal dan memecahkannya sebesar $61,72 \%$ dengan kategori sedang.

\section{Pelaksanaan Tindakan Siklus II}

\section{a. Perencanaan}

Pada dasarnya secara teknis pelaksanaan pembelajaran pada siklus kedua ini sama dengan siklus pertama. Perencanaan tidakan dilakukan dengan mempersiapkan materi lanjutan siklus pertama. Instrumen yang disiapkan pada siklus II meliputi: (1) Rencana Pelaksanaan Pembelajaran

Rencana pelaksanaan pembelajaran (RPP) disusun bersama oleh guru anggota tim (guru 1 dan guru 2) dengan karakteristik pembelajaran menggunakan team teaching yang difokuskan pada motivasi belajar matematika siswa dan berdasarkan refleksi siklus I. Dan menggunakan strategi kooperatif tipe belajar bersama (learning together). Materi yang diajarkan pada pertemuan pertama siklus II yaitu menyelesaikan persamaan kuadrat dengan cara melengkapkan kuadrat. Selanjutnya pada pertemuan kedua siklus II yaitu menyelesaikan persamaan kuadrat dengan menggunakan rumus kuadrat; (2) Menyiapkan Media Media yang akan digunakan dalam proses pembelajaran yaitu teaching material, buku paket dan spidol; (3) Lembar Observasi. Lembar observasi disusun berdasarkan rancangan pelaksanaan pembelajaran yang telah dibuat dan digunakan untuk mencatat hasil pengamatan selama pelaksanaan proses pembelajaran. Hal-hal yang diobservasi yaitu: perencanaan pembelajaran, pelaksanaan pembelajaran yang meliputi kegiatan awal pembelajaran, kegiatan inti pembelajaran, dan penutup, serta refleksi. Disertakan pula pada lembar observasi berupa kolom catatan dan hambatan. Lembar observasi diisi oleh rekan 
sejawat peneliti; (4) Angket Motivasi Belajar Siswa. Angket motivasi belajar siswa disusun untuk mengetahui motivasi belajar matematika siswa setelah pelaksanaan team teaching.

\section{b. Pelaksanaan Tindakan}

Pada tahap ini peneliti dan guru melaksanakan tindakan sesuai dengan rancangan pelaksanaan pembelajaran (RPP) yang telah disusun bersama oleh guru 1 dan guru 2. Selama pembelajaran berlangsung, pengamatan dilakukan oleh rekan sejawat. Pada siklus II pembelajaran dilaksanakan dalam dua kali pertemuan. Pertemuan pertama membahas tentang menyelesaikan persamaan kuadrat dengan cara melengkapkan kuadrat. Sedangkan pertemuan kedua membahas tentang menyelesaikan persamaan kuadrat dengan menggunakan rumus kuadrat.

\section{Hasil Tindakan Siklus II}

Pada pertemuan siklus II ini, siswa tampak lebih antusias dibandingkan siklus I. Gangguan yang ditimbulkan oleh siswa lain sudah berkurang. Secara umum siswa mulai tampak lebih serius mengikuti pembelajaran.

Tabel 5. Hasil Perhitungan Skor Observasi Kegiatan Pembelajaran Matematika Melalui Pelaksanaan Team Teaching Siklus II

\begin{tabular}{|l|l|l|c|c|}
\hline \multirow{2}{*}{ No } & \multirow{2}{*}{ Tahap Pembelajaran Team Teaching } & \multicolumn{2}{|c|}{ Persentase Keterlaksanaan } \\
\cline { 3 - 4 } & & Pertemuan I & $\begin{array}{c}\text { Pertemuan } \\
\text { II }\end{array}$ \\
\hline 1 & Perencanaan pembelajaran & $100 \%$ & $100 \%$ \\
\hline 2 & $\begin{array}{l}\text { Pelaksanaan } \\
\text { Pembelajaran }\end{array}$ & Kegiatan awal & $100 \%$ & $100 \%$ \\
\cline { 3 - 5 } & Kegiatan inti & $100 \%$ & $100 \%$ \\
\cline { 3 - 5 } & Penutup & $100 \%$ & $100 \%$ \\
\hline 3 & Refleksi & $100 \%$ & $100 \%$ \\
\hline \multicolumn{2}{|r|}{ Keterlaksanaan } & $100 \%$ & $100 \%$ \\
\hline \multicolumn{2}{|r|}{ Rata-rata Keterlaksanaan } & \multicolumn{2}{|c}{$\mathbf{1 0 0} \%$} \\
\hline
\end{tabular}

Dari tabel 5 dapat dilihat bahwa persentase rata-rata hasil observasi mencapai $100 \%$ dimana pada pertemuan pertama dan pertemuan kedua mencapai $100 \%$. Hal ini karena mulai tahap perencanaan, tahap pelaksanaan dan refleksi sudah memenuhi ketentuan pelaksanaan team teaching. Pada tahap pelaksanaan yang meliputi kegiatan awal, kegiataninti dan penutup telah dilaksanakan sesuai rancangan pelaksanaan pembelajaran (RPP) yang telah dibuat.

Cerminan motivasi belajar siswa terlihat dari hasil angket yang diisi oleh siswa. Angket diberikan kepada siswa untuk melihat motivasi belajar siswa, Angket diberikan pada setiap akhir pelaksanaan penelitian (siklus). Angket digunakan untuk memperkuat adanya tingkat motivasi belajar siswa, setelah penerapan pembelajaran dengan team teaching. Tabel perolehan skor motivasi belajar siswa adalah sebagai berikut: 
Tabel 6 Hasil Perhitungan Skor Angket Motivasi Belajar Siswa Siklus II

\begin{tabular}{|l|l|l|}
\hline \multicolumn{1}{|c|}{ Indikator } & \multicolumn{1}{c|}{ Persentase } & \multicolumn{1}{c|}{ Kategori } \\
\hline Ketekunan menghadapi tugas & $86,41 \%$ & Tinggi \\
\hline Keuletan dalam menghadapi kesulitan & $87,89 \%$ & Tinggi \\
\hline $\begin{array}{l}\text { Senang dan rajin, penuh semangat, dan } \\
\text { tidak cepat bosan dengan tugas-tugas } \\
\text { rutin }\end{array}$ & $90,23 \%$ & Tinggi \\
\hline Dorongan untuk berprestasi & $86,33 \%$ & Tinggi \\
\hline $\begin{array}{l}\text { Keinginan mendalami lebih jauh materi } \\
\text { yang dipelajari }\end{array}$ & $86,13 \%$ & Tinggi \\
\hline $\begin{array}{l}\text { Usaha untuk berprestasi sebaik } \\
\text { Mungkin }\end{array}$ & $92,58 \%$ & Tinggi \\
\hline Mengejar tujuan jangka panjang & $89,45 \%$ & Tinggi \\
\hline $\begin{array}{l}\text { Dapat mempertanggungjawabkan } \\
\text { pendapat-pendapatnya }\end{array}$ & $87,89 \%$ & Tinggi \\
\hline $\begin{array}{l}\text { Minat terhadap bermacam-macam } \\
\text { Masalah }\end{array}$ & $88,28 \%$ & Tinggi \\
\hline $\begin{array}{l}\text { Senang mencari soal dan } \\
\text { Memecahkannya }\end{array}$ & $80,08 \%$ & Tinggi \\
\hline \multicolumn{1}{|c|}{ Persentase total } & $\mathbf{8 7 , 2 8 ~ \% ~}$ & tinggi \\
\hline
\end{tabular}

\section{d. Refleksi Siklus II}

\section{1) Refleksi terhadap proses mengajar \\ a) Refleksi hari pertama}

Pada tahap refleksi kali ini, guru 1 memberikan saran kepada guru 2 bahwa siswa yang tidak memperhatikan pelajaran diberikan pertanyaan dan langsung ditegur. Pemberian pertanyaan ini cenderung membuat siswa menjadi lebih memperhatikan pembelajaran yang sedang berlangsung. Guru 2 tidak memberikan saran ataupun kritik kepada guru1 karena guru 1 sudah bagus dalam mengajar.

\section{b) Refleksi hari kedua}

Refleksi kali ini tidak ada saran maupun kritikan dari guru 1 maupun guru 2. Karena kegiatan mengajar sudah bagus dan proses pembelajaran sudah sesuai dengan rencana pelaksanaan pembelajaran yang telah dibuat.

\section{2) Refleksi terhadap proses pembelajaran}

Pada pembelajaran matematika dengan pelaksanaan team teaching dapat dikatakan berjalan secara optimal. Kenyataan ini terlihat dari aktivitas siswa yang cukup tinggi dibandingkan siklus sebelumnya. Indikator yang dapat dijadikan pedoman adalah meningkatnya motivasi siswa mencapai standar yang telah ditetapkan.

Berdasarkan hasil pengamatan terhadap kegiatan pembelajaran matematika pada siklus II, setiap awal pembelajaran guru selalu melakukan apersepsi untuk memotivasi siswa. Siswa pun telah mempelajari terlebih dahulu materi sehingga persiapan siswa lebih matang. Selama kegiatan pembelajaran, guru selalu menciptakan situasi kondusif. Hal ini terlihat setiap kegiatan inti pembelajaran, guru dapat mengelola kelas dengan baik. Setelah guru memberikan tugas kepada 
siswa, secara bergiliran guru dan peneliti mengamati dan memberikan bimbingan. Selanjutnya pada kegiatan penutup guru merangkum materi dan mengklarifikasi pelajaran sebagai penguatan dan melakukan tanya jawab.

Analisis dan refleksi siklus II menunjukkan indikator keberhasilan siswa sudah terpenuhi. Artinya bahwa pelaksanaan pembelajaran matematika sudah sesuai ketentuan yaitu dengan menggunakan metode team teaching dan persentase rata-rata hasil observasi mencapai $100 \%$. Serta rata-rata persentase motivasi belajar matematika siswa secara keseluruhan berada pada kategori tinggi. Maka, tidak perlu adanya siklus selanjutnya.

\section{Hasil Penelitian Tindakan Kelas}

Hasil penelitian tindakan yang telah dilaksanakan meliputi hasil observasi keterlaksanaan team teaching dalam pembelajaran matematika, serta hasil angket motivasi belajar matematika siswa.

1. Hasil observasi keterlaksanaan team teaching

Selama proses pembelajaran menggunakan metode team teaching siklus I dan siklus II dilakukan pengambilan data keterlaksanaan pembelajaran dengan cara observasi. Data keterlaksanaan pembelajaran dengan team teaching pada siklus I dan siklus II ditunjukkan oleh tabel 7.

Tabel 7 mendeskripsikan tentang keterlaksanaan team teaching dalam proses pembelajaran pada siklus I dan siklus II. Keterlaksanaan team teaching pada siklus I adalah 90,48\%. Pelaksanaan pembelajaran tidak terlaksana dengan baik sesuai rancangan pelaksanaan pembelajaran (RPP) yang sudah disusun sehingga pembelajaran yang dilakukan tidak efektif.

Langkah pembelajaran yang tidak terlaksana pada siklus I adalah tidak adanya pembahasan tugas terstruktur karena pada pertemuan sebelumnya tidak diberikan tugas. Hal ini menyebabkan siswa tidak terpancing untuk belajar. Selain itu, tidak diberikan apersepsi tentang materi yang akan dipelajari karena siswa tidak ada persiapan materi.

Kemudian pada saat diskusi kelas, siswa masih enggan menyampaikan pendapatnya. Pada saat bel masuk kelas sudah berbunyi, siswa tidak segera masuk kelas, sehingga banyak waktu yang terbuang yang mengakibatkan berkurangnya waktu untuk kegiatan pembelajaran sehingga pada kegiatan penutup tidak ada waktu untuk merangkum materi yang telah dipelajari.

Tabel 7 Hasil Perhitungan Skor Observasi Kegiatan Pembelajaran Matematika Melalui Pelaksanaan Team Teaching

\begin{tabular}{|l|l|l|c|c|}
\hline \multirow{2}{*}{ No } & \multicolumn{3}{|c|}{ Tahap Pembelajaran Team Teaching } & \multicolumn{2}{|c|}{ Persentase Keterlaksanaan } \\
\cline { 3 - 4 } & & Pertemuan I & $\begin{array}{c}\text { Pertemuan } \\
\text { II }\end{array}$ \\
\hline 1 & Perencanaan pembelajaran & $100 \%$ & $100 \%$ \\
\hline 2 & $\begin{array}{l}\text { Pelaksanaan } \\
\text { Pembelajaran }\end{array}$ & Kegiatan awal & $80 \%$ & $100 \%$ \\
\cline { 3 - 5 } & & Kegiatan inti & $94,44 \%$ & $100 \%$ \\
\cline { 3 - 5 } & & Penutup & $83,33 \%$ & $100 \%$ \\
\hline
\end{tabular}




\begin{tabular}{|c|c|c|c|}
\hline 3 & Refleksi & $100 \%$ & $100 \%$ \\
\hline \multicolumn{2}{|c|}{ Keterlaksanaan } & $\mathbf{9 0 , 4 8 \%}$ & $\mathbf{1 0 0} \%$ \\
\hline
\end{tabular}

Keterlaksanaan team teaching pada siklus II mencapai 100\%. Tahap perencanaan, pelaksanaan dan refleksi sudah berjalan dengan baik. Pada tahap pelaksanaan pembelajaran sudah berjalan sesuai rancangan pelaksanaan pembelajaran (RPP) yang telah dibuat.

2. Hasil angket motivasi belajar matematika siswa

Motivasi siswa meningkat dari siklus I sebesar 74,41\% dengan kategori sedang, menjadi sebesar $87,28 \%$ dengan kategori tinggi pada siklus II. Berdasarkan hasil angket diperoleh, data mengenai tingkat motivasi belajar siswa pada mata pelajaran matematika disajikan dalam tabel halaman berikut ini:

Tabel 8 Hasil Perhitungan Skor Angket Motivasi Belajar Siswa

\begin{tabular}{|l|c|c|}
\hline \multicolumn{1}{|c|}{ Indikator } & Persentase & Kategori \\
\cline { 2 - 3 } & Siklus I & Siklus II \\
\hline Ketekunan menghadapi tugas & $72,34 \%$ & $86,41 \%$ \\
\hline Keuletan dalam menghadapi kesulitan & $78,13 \%$ & $87,89 \%$ \\
\hline $\begin{array}{l}\text { Senang dan rajin, penuh semangat, dan } \\
\text { tidak cepat bosan dengan tugas-tugas } \\
\text { rutin }\end{array}$ & $78,91 \%$ & $90,23 \%$ \\
\hline Dorongan untuk berprestasi & $70,31 \%$ & $86,33 \%$ \\
\hline $\begin{array}{l}\text { Keinginan mendalami lebih jauh materi } \\
\text { yang dipelajari }\end{array}$ & $72,66 \%$ & $86,13 \%$ \\
\hline $\begin{array}{l}\text { Usaha untuk berprestasi sebaik } \\
\text { Mungkin }\end{array}$ & $84,77 \%$ & $92,58 \%$ \\
\hline Mengejar tujuan jangka panjang & $80,08 \%$ & $89,45 \%$ \\
\hline $\begin{array}{l}\text { Dapat mempertanggungjawabkan } \\
\text { pendapat-pendapatnya }\end{array}$ & $73,44 \%$ & $87,89 \%$ \\
\hline $\begin{array}{l}\text { Minat terhadap bermacam-macam } \\
\text { Masalah }\end{array}$ & $76,56 \%$ & $88,28 \%$ \\
\hline $\begin{array}{l}\text { Senang mencari soal dan } \\
\text { Memecahkannya }\end{array}$ & $61,72 \%$ & $80,08 \%$ \\
\hline \multicolumn{1}{|c|}{ Persentase total } & $\mathbf{7 4 , 4 1} \%$ & $\mathbf{8 7 , 2 8 \%}$ \\
\hline
\end{tabular}

Berdasarkan hasil angket diperoleh rata-rata tingkat motivasi siswa pada siklus 1 sebesar 74,41\% (sedang) dan pada siklus 2 sebesar 87,28\% (tinggi). Hasil tersebut dibagi menjadi beberapa indikator, yaitu: (a) Ketekunan menghadapi tugas pada siklus 1 sebesar 72,34\% dalam kategori sedang, meningkat pada siklus 2 sebesar 86,41\% dalam kategori tinggi; (b) Keuletan dalam menghadapi kesulitan pada siklus 1 sebesar 78,13\% dalam kategori tinggi, meningkat pada siklus 2 sebesar 87,89\% dalam kategori tinggi; (c) Senang dan rajin, penuh semangat, dan tidak cepat bosan dengan tugas-tugas rutin pada siklus 1 sebesar 78,91\% dalam kategori tinggi, meningkat pada siklus 2 sebesar 90,23\% dalam kategori tinggi; (d) Dorongan untuk berprestasi pada siklus 1 sebesar 70,31\% dalam kategori sedang, meningkat pada siklus 2 sebesar 86,33\% dalam kategori tinggi; (e) Keinginan 
mendalami lebih jauh materi yang dipelajari pada siklus 1 sebesar 72,66\% dalam kategori sedang, meningkat pada siklus 2 sebesar 86,13\% dalam kategori tinggi; (f) Usaha untuk berprestasi sebaik mungkin pada siklus 1 sebesar $84,77 \%$ dalam kategori tinggi, meningkat pada siklus 2 sebesar 92,58\% dalam kategori tinggi; (g) Mengejar tujuan jangka panjang sebesar pada siklus 1 sebesar 80,08\% dalam kategori tinggi, meningkat pada siklus 2 sebesar 89,45\% dalam kategori tinggi; (h) Dapat mempertanggungjawabkan pendapat-pendapatnya pada siklus 1 sebesar 73,44\% dalam kategori sedang, meningkat pada siklus 2 sebesar 87,89\% dalam kategori tinggi; (i) Minat terhadap bermacam-macam masalah pada siklus 1 sebesar 76,56\% dalam kategori tinggi, meningkat pada siklus 2 sebesar 88,28\% dalam kategori tinggi; dan (j) Senang mencari soal dan memecahkannya pada siklus 1 sebesar 61,72\% dalam kategori sedang, meningkat pada siklus 2 sebesar $80,08 \%$ dalam kategori tinggi.

\section{Pembahasan}

Pada penelitian ini, pelaksanaan team teaching pada pembelajaran matematika dipandang telah memberikan kontribusi terhadap peningkatan motivasi belajar siswa kelas X-TO SMK Negeri 1 Robatal Kabupaten Sampang. Siswa yang semula menunjukkan sikap tidak berminat dan kurangnya motivasi pada pelajaran matematika seperti: masuk kelas terlambat, selalu gaduh, tidak memperhatikan guru, cepat menyerah dalam menyelesaikan soal karena guru tidak dapat membimbing siswa secara individual.

Tahap awal pelakasanaan team teaching yakni guru yang tergabung dalam tim bersama-sama menyusun perencanaan yang matang. Meliputi pembuatan rencana pelaksanaan pembelajaran (RPP), pemilihan metode, pemahaman materi dan isi pembelajaran, serta pembagian peran dan tanggung jawab secara jelas.

Pada tahap inti semua guru yang tergabung dalam tim berada di dalam kelas dengan posisi dan tugas yang telah diatur dalam perencanaan. Dalam pelaksanaan pembelajaran matematika ini digunakan team teaching model supported instruction dipadukan dengan model monitoring teacher. Dimana supported instruction adalah bentuk team teaching dengan salah seorang guru menyampaikan materi pelajaran, sedangkan guru lainnya melakukan kegiatan tindak lanjut dari materi yang telah disampaikan rekan satu timnya tersebut.

Sedangkan model monitoring teacher adalah bentuk team teaching dengan salah seorang guru melakukan pembelajaran di kelas, sedangkan yang lainnya berkeliling untuk memonitor perilaku dan kemajuan siswa. Pendekatan yang digunakan adalah metode cooperative learning tipe belajar bersama (learning together). Dalam learning together, para siswa dibagi dalam kelompok belajar yang terdiri atas empat orang siswa yang berbeda-beda tingkat kemampuan, jenis kelamin, dan latar belakang etniknya.

Hal tersebut terlihat dari hasil analisis angket motivasi belajar siswa yang menunjukkan terjadi peningkatan dari tiap siklusnya. Motivasi tersebut secara keseluruhan pada siklus I sebesar $74,41 \%$ dengan kategori sedang, menjadi sebesar $87,28 \%$ dengan kategori tinggi pada siklus II.

Berdasarkan data yang diperoleh dari hasil observasi, angket motivasi belajar siswa, dan catatan lapangan, peneliti menyimpulkan bahwa kegiatan pembelajaran matematika dengan metode team teaching di kelas X-TO SMK Negeri 
1 Robatal berjalan lancar sesuai rencana yang telah disusun. Selain itu, tujuan dari tindakan untuk meningkatkan motivasi belajar siswa juga tercapai.

\section{Kesimpulan}

Berdasarkan hasil penelitian dan pembahasan maka dapat disimpulkan sebagai berikut:

1.Pelaksanaan team teaching agar dapat meningkatkan motivasi belajar matematika siswa kelas X-TO SMK Negeri 1 Robatal yaitu guru anggota team teaching yang terdiri dari guru matematika kelas X SMK Negeri 1 Robatal bertindak sebagai guru 1 dan peneliti sebagai guru 2, melaksanakan team teaching dengan tahap-tahap:

a. Perencanaan pembelajaran:

1) Guru 1 dan guru 2 bersama-sama menyusun Rancangan Pelaksanaan Pembelajaran (RPP) dengan menetapkan metode pembelajaran kooperatif tipe belajar bersama (learning together).

2) Guru 1 dan guru 2 berdiskusi tentang pembagian peran dan tanggung jawab guru anggota team teaching serta pembagian pos-pos pengawasan di dalam kelas.

3) Guru 1 dann guru 2 bekerjasama menyusun teaching material yang berisi materi, LKS, latihan soal dan penugasan terstruktur.

4) Guru 1 dan guru 2 menyiapkan media dan perangkat pembelajaran.

b. Pelaksanaan pembelajaran

Semua anggota team teaching berada di dalam kelas dengan posisi dan tugas yang telah diatur dalam perencanaan. Guru anggota team teaching bekerjasama melaksanakan pembelajaran sesuai RPP dan metode yang ditetapkan.

c. Evaluasi

Guru anggota team teaching berdiskusi mengenai pelaksanaan pembelajaran agar diperoleh berbagai rumusan perbaikan yang tepat untuk pembelajaran berikutnya.

2. Implementasi metode team teaching dapat meningkatkan motivasi belajar matematika siswa kelas X-TO SMK Negeri 1 Robatal. Hal ini terlihat dari peningkatan persentase angket motivasi belajar siswa secara keseluruhan pada siklus I sebesar 74,41\% dengan kategori sedang dan pada siklus II sebesar $87,28 \%$ dengan kategori tinggi.

\section{Daftar Pustaka}

Asmani, Jamal Ma'mur, Pengenalan dan Pelaksanaan Lengkap Micro Teaching \& Team Teaching. (Yogyakarta: Diva Press, 2017).

Arikunto, Suharsimi, Prosedur Penelitian; Suatu Pendekatan Praktik. (Jakarta: Rineka Cipta, 2006).

Baharuddin \& Esa Nur Wahyuni, Teori Belajar dan Pembelajaran. (Jakarta: Ar-Ruzz Media, 2007). 
Beggs, David W., Team Teaching Bold New Venture. (Bloomington:

Indiana

University Press, 1971).

Dalyono, M., Psikologi Pendidikan. (Jakarta: Rineka Cipta, 1997).

Davis, Ivor K., Pengelolaan Belajar. (Jakarta: Rajawali Pers, 1991).

Davis, Robert H., Lawrence T. Alexander \& Stephen L. Yelon, Learning System Design an Approach to The Improvement of Instruction. (Michigan:Michigan State University, 1974).

Dharma, Surya, Strategi Pembelajaran dan Pemilihannya. (Jakarta: Depdiknas, 2008).

Suherman, Erman dkk., Strategi Pembelajaran Matematika Kontemporer. (Bandung: UPI, 2003).

Hamalik, Oemar, Proses Belajar Mengajar. (Jakarta: Bumi Aksara, 2005).

Harjana, Agus M., Kiat Sukses Studi di Perguruan Tinggi. (Yogyakarta: Kanisius, 1994).

Houston, John P., Motivation. (New York: Macmillan Publishing Company, 1985).

Munandar, Utami, Mengembangkan Bakat dan Kreativitas Anak Sekolah. (Jakarta: Gramedia, 1992).

Prayitno, Elida, Motivasi dalam Belajar. (Jakarta: Departemen Pendidikan Kebudayaan, Direktur Jenderal Pendidikan Tinggi, 1989).

Purwanto, Ngalim, Psikologi Pendidikan. (Bandung: Rosda Karya, 1990).

Roestiyah \& Yumiati Suharto, Strategi Belajar Mengajar. (Jakarta: Bina Aksara, 1985).

Rohani, Ahmad, Pengelolaan Pengajaran. (Jakarta: Rhineka Cipta, 1990).

Sabri, Alisuf, Psikologi Pendidikan. (Jakarta: Pedoman Ilmu Jaya, 1996).

Sardiman, A.M., Interaksi dan Motivasi Belajar Mengajar. (Jakarta: Citra Perkasa Sejati Offset, 1996).

Sardiman, AM., Interaksi dan Motivasi Belajar. (Jakarta: Rajawali Pers, 2001).

Slavin, Robert E., Cooperative Learning Teori, Riset dan Praktik. (Bandung: Nusa Media, 2017).

Sugihartono dkk., Psikologi Pendidikan. (Yogyakarta: Universitas Negeri Yogyakarta Pers, 2007).

Usman, Moh. Uzer, Menjadi Guru Profesional. (Bandung: Rosda Karya, 1995). 